\title{
The importance of Trademarks and a review of empirical studies
}

\author{
Mirësi Çela ${ }^{1}, \mathrm{PhD}$ Candidate
}

\begin{abstract}
Many studies have been focused on innovation and patents, less emphasis is given to trademarks, even though these intellectual property assets are more widely used by firms of all types across the whole economy. Various international treaties have been established in order to harmonize the different trademark's registration procedures across countries, and to simplify the application process for applicants targeting multiple countries. The aim of this paper is to make a review of some of the empirical studies done by scholars with trademarks in focus. Which are the motives that urge firms to register a trademark. How are trademarks related to innovation and firm's size. At the end the paper concludes with some key messages on trademarks and their use by firms.
\end{abstract}

Keywords: trademarks, innovation, empirical studies, intellectual property

\section{Introduction}

Much less attention has been paid to trade marks, even though these intellectual property assets are more widely used by firms of all types across the whole economy. A growing empirical economic literature is now emerging that explores the expanding use of trademarks and tries to evaluate the economic role and impact of this type of intellectual property (Millot, 2009). Being a source of visibility and reputation, trademarks become a strategic asset to firms competing on the basis of product differentiation and customer loyalty. When successful, trademarks become associated with perceived value to users and, consequently, are a source of higher margins for the firms that fill them. Both innovative and non-innovative firms use trademarks, one of the main forms of intellectual property rights. The primary economic function of trademarks is not - as with patents - to give firms incentives to invest in research and development, but to signal quality and good will, to enhance efficiency by reducing consumer search costs, and to support firm branding efforts (Davies \& Davies, 2011).This paper is organized as follows: the first part deals with the importance of trademarks, their use and next the main drivers of trademarks growth of registrations are discussed. What are the International Agreements and Treaties related to trademarks, what is the number of applications and the growth rates of filed applications. There are many studies geographically dispersed from developed countries to the developing one, which try to evaluate the correlation with innovation, firms' economic performance and firms' size. The second part aims to make a review of the empirical studies done by scholars with trademarks in focus. 


\section{Defining Trademarks}

Article 15 of the Agreement on Trade related aspects of Intellectual property Rights (TRIPs) ${ }^{1}$ provides a definition of trademarks stating that:

"Any sign, or any combination of signs, capable of distinguishing the goods or services of one undertaking from those of other undertakings, shall be capable of constituting a trade mark"

There are several dimensions in this definition

Firstly, a trade mark is defined in substance: a sign. It can be denominations, letters, numerals, combination of colors, or any combinations of these elements.

Secondly, a trademark is defined by its function, the sign has to be distinctive. Originally the trademark law was designed to fulfill the public policy objective of consumer protection. It prevents the public from being misled as to the origin or quality of products.

Thirdly, a trademark is defined in legal terms: It is a type of industrial property. Trademark protection grants the owner the exclusive right to use the signs to identify the goods or services produced or to authorize another party to use them in return of payment. Practically, the owner can be any physical or legal person, (the majority of trademarks are owned by firms). Trademarks are defined as a combination of these different dimensions.(Millot, 2012)

\section{International Agreements on Trademarks}

Various international treaties have been established in order to harmonize the different TM registration procedures across countries, and to simplify the application process for applicants targeting multiple countries. Besides the Paris Convention and the TRIPS, which harmonize the trademark procedure across countries, the most important international agreement for trademarks is the Madrid Protocol, which allows trademark owners to ask for protection in several countries by filing only one application. Yet, it is not possible to file a single trade mark registration which would automatically apply around the world. In the European community, since 1994, trademark owners can register a trademark which is valid throughout the European Community, through the Community Trademark (CTM) system.

\subsection{Treaties governing registration systems for obtaining protection}

Thanks to the various international treaties, the trademark systems are relatively harmonized worldwide. Besides, thanks to the registration systems, trademark datasets are available with information on the owner, its geographical origin and the dates of application and registration.

1 The TRIPs Agreement, signed in 1994 as a founding element of the WTO, represents the most important attempt to establish a global harmonization of Intellectual Property protection. It has been described as "the most significant international undertaking on IPR in history", (Maskus, 2000) 


\subsubsection{The Madrid System for international registration of marks - 1891-1989}

The Madrid system is the major international system for facilitating the registration of trademarks in multiple jurisdictions. It was established in 1891 and is governed by two treaties. the Madrid Agreement (1891) ${ }^{2}$ and the Madrid Protocol (1989)3. It is administered by the International Bureau of WIPO (World Intellectual Property Organization). It offers a TM owner the possibility of having his TM protected in several countries members of the Madrid Union, by simply filing one application in one jurisdiction with one set of fees. States and organizations party to the Madrid system are collectively referred to as Contracting Parties.

\subsubsection{The Community Trade Mark (CTM) System - 1994}

The CTM system, established in 1994, is intended to give proprietors the possibility of registering a trademark with validity throughout the European Community. The registration of a TM with the Office for Harmonization in the Internal Market (OHIM, European TM office) leads to a right which is effective throughout the European Community as a whole. CTM registration applies indivisibly across all European Community member states. An objection against a CTM application in any member state can defeat the entire application; if there is none, the CTM registration is enforceable in all member states. Nevertheless, the CTM system did not replace the national TM registration systems: they operate in parallel to each other (Millot, 2009).

\subsection{Madrid International applications}

In order to file a Madrid international application, applicants must have first applied for a trademark registration with their respective home IP office that represents a Madrid member country or region. On the basis of this original application or registration issued therefore, the trademark applicant or holder benefits from the option to seek protection for this trademark internationally in other Madrid member countries by submitting an international application with their respective domestic IP office.

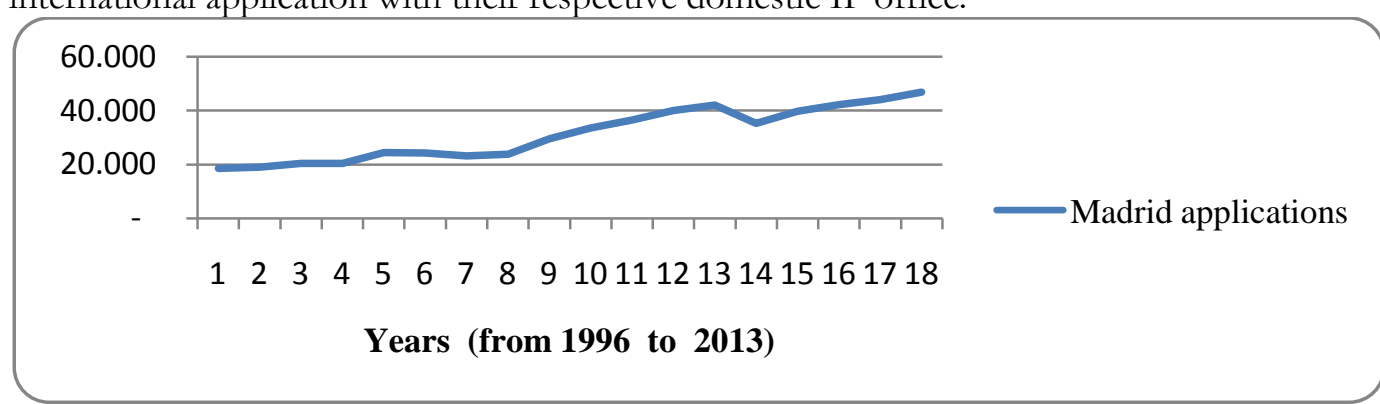

Figure 1: Madrid International applications

Source: WIPO Statistics Database, March 2014

2The Madrid Agreement, which was concluded in 1891 and revised at Brussels (1900), Washington (1911), The Hague (1925), London (1934), Nice (1957) and Stockholm (1967), and amended in 1979.

${ }^{3}$ Madrid Protocol, which is the Protocol relating to that Agreement, concluded in 1989, which aims to make the Madrid system more flexible and more compatible with the domestic legislation of certain countries or intergovernmental organizations that had not been able to accede to the Agreement. 
Figure 1 presents the numbers of international applications filed via all Madrid member IP offices.

In year 2013, 46,829 Madrid international applications were filed, thus reaching their highest level ever recorded. In fact, over the 18- year period presented their numbers have increased for all but three years that coincided with economic downturns in the early 2000s and 2009. This prevailing growth is partly due to factors such as increased usage of the Madrid system and its expanded membership, coupled with a general upward trend in trademark application volumes worldwide. In 1996, the number of Madrid system member countries totaled just 50. By 2004, membership had increased to 77 , following the addition of several larger members, including the Republic of Korea, the United States of America (US) and the European Union (EU). This in turn led to a spike in the number of international applications filed. By 2008, the Madrid System counted 84 members before reaching its current 92 in 2013.(WIPO, 2014)

\subsection{Motives for trademarks registration}

In their study Flikkema, De Man, \& Wolters (2010) from twenty they deduced four underlying_motives of trademark registration.

The first one is to leverage other firm assets. This motive relates to trademarks that are used to increase the value of assets a company already possesses, be it the company image, customer base or negotiation power. A new brand can strengthen any of these assets.

The second motive is to emphasize the importance of product or market innovation to both firm insiders and outsiders. A new trademark will show that something new is happening and acts as a signaling device for this.

The third motive is to improve the marketability of firm assets. If an asset is marked, this is an indication that it is valuable and helps in exploiting that asset in the market, because it becomes a recognizable entity. It is to prevent marketing imitation. By claiming a trademark, direct imitation by a competitor is made more difficult. (Flikkema et al., 2010)

A final view of trade marking reflects the change in management practices Greenhalgh \& Rogers (2007) call this "the management fad" view. It is possible that the increased use of trademarks is largely due to changing management practices and, specifically, a rush by managers to copy rivals' activities, rather than any inherent value relevance for trademarks per se. Such a view also raises concerns over the possibility of reverse causation: managers of high productivity firms may have more discretionary funds and allocate some of these to copying the latest management fad.

\subsection{Benefits of Trademarks}

What is the impact of trademarks on social welfare? This question have put economists to have divergent opinions. Landes and Posner (1987), in their founding paper of the "Law and Economics Approach", argue that trademark law can be explained on the hypothesis that the law is trying to promote economic efficiency. The basic argument is that trademarks are economically beneficial since they help to solve the information 
asymmetry ${ }^{4}$ issue between sellers and buyers, highlighted by Akerlof (1970). Firms use trademarks to signal to consumers that the product is of a certain quality. Landes and Posner build a formal model based on the integration of the consumer search costs whilst choosing his products: the full price of the good comprises both the money price and the search costs. The investments of firms in trademarks reduce the search costs, so that the firm can charge a higher money price, and increase its profit.

When differentiated quality is introduced, the model also predicts that higher trademark investment goes with higher quality of products. So, trademarks reach a sort of social optimum (Millot, 2009).

In the broad debate on the merits of IP instruments, social costs and benefits are generally understood as global concepts. A region can gain a competitive advantage over other regions if the firms located there also gain a competitive advantage and if the value added that results is more than proportionately retained within the region. Thus a global social cost that results from monopoly distortion is consistent with a regional benefit if the firm is located within the region. The reason why regional agencies are keen to promote trade marking among local firms is, presumably, to facilitate the creation and retention of monopoly rents within the region. (Mainwaring, Moore, \& Murphy, 2004)

\subsection{Empirical studies on trademarks}

There are several empirical studies including trademarks, patents or other forms of intellectual property. Recently, there has been an increased interest in the use of trademarks. The main themes are a) the patterns of firm's usage of trademarks in relation to their innovation activities and new products, b) trademarks relations to firm's economic performance and c) trademarks and firm's size.

\subsubsection{Trademarks and innovation}

To conceptualize how trademarks can affect innovation when seen both as exclusive rights and as signals of quality and intent, Davies and Davies (2011) have developed the matrix, below. As can be seen from Figure 4, trademarks as exclusive rights can function as the legal basis for both weak (or non-existent) entry barriers and strong entry barriers. Trademarks can protect both novel and non-novel goods. There are four scenarios:

1. The trademark both protects an invention that is novel and is effective as an entry barrier;

2. The trademarked invention protects a product that is novel, but is ineffective as an entry barrier;

3. The trademark protects a product that is non-novel, but is effective as an entry barrier;

4. The trademark both protects a product that is non-novel, and is ineffective as an entry barrier.

4 information asymmetry; for more explanation see (Akerlof, 1970); The market for "Lemons": Quality Uncertainty and Market Mechanism. 
Table 1: Four scenarios: Trademarks and innovation:

\begin{tabular}{|c|c|c|c|}
\hline \multicolumn{4}{|c|}{ Trademarks as entry barriers } \\
\hline & & Strong & Weak \\
\hline \multirow[t]{2}{*}{$\begin{array}{l}\text { Trademarks } \\
\text { as signals of } \\
\text { novelty }\end{array}$} & $\begin{array}{l}\text { To protect a } \\
\text { novel good }\end{array}$ & $\begin{array}{l}\text { The trademark protects a } \\
\text { novel product, process or } \\
\text { service and is effective as an } \\
\text { entry barrier, }\end{array}$ & $\begin{array}{l}\text { The trademark protects a novel } \\
\text { product, process or service, but } \\
\text { is ineffective as an entry barrier, } \\
\text { enabling other firms to enter the } \\
\text { market and appropriate a good } \\
\text { portion of the rents. }\end{array}$ \\
\hline & $\begin{array}{l}\text { To protect a } \\
\text { non- novel } \\
\text { good }\end{array}$ & $\begin{array}{l}\text { The trademark is effective as } \\
\text { an entry barrier, but protects } \\
\text { a non- novel product, process } \\
\text { or service, with the result that } \\
\text { the firm might lose its } \\
\text { incentive to continue to } \\
\text { innovate in relation to } \\
\text { changing market and } \\
\text { technological conditions }\end{array}$ & $\begin{array}{l}\text { The trademark is effective as an } \\
\text { entry barrier, but protects a } \\
\text { non- novel product, process or } \\
\text { service, with the result that the } \\
\text { firm might lose its incentive to } \\
\text { continue to innovate in relation } \\
\text { to changing market and } \\
\text { technological conditions }\end{array}$ \\
\hline
\end{tabular}

Source : Davies and Davies (2011)

According to (Brahem, M.,El Harbi, S. and Grolleau, G., 2013) which study the determinants of trademark registration among Tunisian apparel firms . They analyze 116 questionnaires with a response rate of $70 \%$. The dependent variable, $\mathrm{Y}$, refers to the trademark registration and also are included four variables to have an impact on trade marking activity. They are; 1) The degree of product innovation, 2) Geographical market diversification, 3) Investment in quality improvement, 3) Willingness to take financial risk, and two control variables firm's licensing activity (as suggested by previous studies e.g.(Gambardella, Giuri, \& Luzzi, 2007) and firm's size. The results show that a high degree of innovation increases the chance of trademark registration. Their results confirm the study of Malmberg (2005) that trademark registration is correlated to innovation activities of firms. The impact of geographical market diversification on trademark registration is positive, investment in quality improvement is positively and significantly associated with trademark registration, consistent with the literature,(Fink et al.,2005). Also firm's willingness to take financial risk influences on trademarks registration, confirm of the results given by (Jensen \& Webster, 2006).

(Mendonça, Pereira, \& Godinho, 2004), in their study on registered trademarks in the European Union, points out the first five countries in the classification of the trademarks registration, are at the same time the most powerful economies on the continent. They are responsible for the $80 \%$ of the applications. Another study conducted by the author on a sample of Portuguese companies demonstrates that the high tech sector utilizes more trademarks than the low-tech firms. This signals the significance at trademarks as innovation indicator.

Into the relevance of trademarks for measuring innovation, the authors conclude that innovation plays a role as a motive for trademark registration, but that it seems to be a subordinate role. (Flikkema et al., 2010) states that trademarks provide exclusive rights, but no incentive for innovation per se. However, this does not mean that trademarked 
products or services are not innovative. A new, innovative product may primarily be trademarked for other motives than innovation or the motives may be related to innovation.

Schwiebacher, (2012) in his study for German companies shows by the analysis a complementary relationship between patent and trademark protection. Inventions or technological novelties do not speak for themselves. Companies have to care about a clear communication strategy to potential customers concerning their technological capabilities. Thus, companies benefit when they use trademarks to complement the innovative content of their products.

For company strategy, their results imply that managers should carefully consider whether company's customer base is informed about the performance characteristics of the product portfolio. The analysis shows that combining patents and trademarks can thereof lead to a higher sales share with new products. In the end, managers need to perform a cost-benefit- analysis. Trademark protection is only useful when combined with marketing expenses and applying for patents is also costly.

\subsubsection{Trademarks and firm's performance}

Some of empirical studies which measure the impact of trademarks and firm's performance, are as follows:

Greenhalgh \& Rogers ( 2007) in their study found a positive correlation between trademarks registration and product innovation, productivity and productivity of firms. Their study was conducted on a sample of firms in UK, that have registered trademarks in UK and European Union during 1996-2000 period. As dependent variable they use the Tobin's Q, considering that the market value of the firm reflects the expectations of future profitability relative to intangible assets. The study has put in evidence strong differences between firms that have registered a trademark and those that have not. This gap is more prominent in the services firms. The same hypotheses are confirmed by Helmers \& Rogers ( 2008), in their study of survival of small, medium and start -up firms in UK; from their analysis result $s$ that firms that use IPR, in particular use trademarks, have major chances of survival.

Another study of (Griffith et al., 2005) analyzing profits of a sample of Australian firms, the authors have proven that that the presence of patents first and then trademarks in the Intellectual Property portfolio is positively related with sales.

Krasnikov, Mishra, \& Orozco, (2009) conducted an analysis in the period 1995- 2005, on a sample of American firms, searching for a correlation between the trademark registration and their financial performance. The analysis shows that exists a strong correlation between trademarks and the cash flow the Tobin ' $\mathrm{Q}$, the stock value and cash flow variability.

\subsubsection{Trademarks and firm's size}

Even if one can argue that trademarks are more easily available and cheaper than patents, there are few econometric studies that use trademark data in order to directly analyze firms' characteristics and especially firm size as a determinant to use trademarks. 
A descriptive exercise done on Norwegian firms, gives some clues on SMEs' likelihood to use trademarks. Gathering several thousands of applicants, including micro firms and SMEs, (Iversen, 2003) underlines that less than 30\% of the smallest firms identified were involved in two or more trademark applications whereas the percentage rises to $90 \%$ for large enterprises. This rough analysis suggests a positive correlation between size and the number of trademark applications.

(Mamede \& Fernandes, 2011)conducted a study in Portugal, their regression results largely confirmed the notion that firm size and age are relevant determinants of trademark use. In particular, new firms reveal a higher propensity for trade marking, while trademark use is more probable among bigger firms than in smaller ones. The regression results also show that geographical proximity plays an important role in explaining the trademark use by firms (even after controlling for the higher propensity of firms located in metropolitan centers to use trade marks). In fact, the regional effect showed to be more important than the industry effect.

Notwithstanding, according to the authors idiosyncratic features of firms constitute the most important determinants of trademark use. We were able to capture only part of such features, by considering the educational background of the employers. Their results show that having a university degree holder, especially if she graduated in Business Studies, increases the probability of a firm adhering to this type of industrial property.

Mainwaring et al.(2004). Applying a zero-inflated Poisson model to explain trademark counts on 3500 firms located in three British regions and Ireland, the authors find that trademark counts increase with firm size. The specification does not directly estimate the impact of firm size on the intensity of using trademarks. However, marginal effects suggest that large firms could be using trademarks more intensively.

Allegrezza and Guard - Rauchs in their study in (1999) as cited by Schautschick and Greenhalgh, (2013) attempt to explain the mechanisms that are linked with a firm's decision to deposit e trademark. They find a significant positive relationship between trade-marking and R\&D intensity, as measured by the frequency of R\&D activity in the firm. Given that R\&D is often used to proxy innovative activity, this seems to indicate links between innovation and trade marks. However, given the small range of industries in which firms conduct formal R\&D, mainly manufacturing, this study is by no means definitive. The results give evidence that larger firms are more likely to register a trademark. Despite a large sample size, results are not that interesting since the dependent variable does not measure the number of trademarks but rather the likelihood to file at least one trademark.

\subsection{Concluding remarks}

The value of trademarks has been demonstrated through various brand rankings and in recent studies conducted in the United States and the European Union and by the World Intellectual Property Organization (WIPO) and many other scholars interested in the field of intellectual property in general and trademarks in particular. They address many questions, and the variables they take in considerations vary from firms' size, their financial performance, the use of trademark as innovation indicator and a combination 
of them. They show a positive correlation trademarks and firm size, financial performance, and in many cases serves as indicator to show how innovative firms are.

\section{References}

Akerlof, G. a. (1970). The Market for "Lemons": Quality Uncertainty and the Market Mechanism. The Quarterly Journal of Economics, 84(3), 488-500. doi:10.2307/1879431

Brahem, M.,El Harbi, S. and Grolleau, G. (2013). What drives trademarks registration among Tunisian clothing firms? An econometric investigation. International Journal of Intellectual Property Management, 6, 1-14. doi:10.1504/IJIPM.2013.053447

Davies, L., \& Davies, J. (2011). To What Extent Do Trademarks Enhance - or Hinder - Innovation? Exploring an inriguing yet Ambiguous Relationship. Retrieved from http://www.epip.eu/conferences/epip06/files/1314905242_.pdf

Fink, C., Javorcik, B. S., \& Spatareanu, M. (n.d.). Income -Related Biases in International Trade: What Do Trademark Registration Data Tell Us? Retrieved October 29, 2014, from http://www.cb.cityu.edu.hk/ef/PastEvent/Sem2004_24May2004/pdf/session 2_3.pdf

Flikkema, M. J., de Man, A. P., \& Wolters, M. J. (2010). New trademark registration as an indicator of innovation: results of an explorative study of Benelux trademark data. http://dspace.ubvu.vu.nl/bitstream/handle/1871/16297/2010-9.pdf?sequence=2

Gambardella, A., Giuri, P., \& Luzzi, A. (2007). The market for patents in Europe. Research Policy,36(8),11631183. http://www.econstor.eu/bitstream/10419/89449/1/512141126.pdf

Schautschick, P., \& Greenhalgh, C. (2013). Empirical studies of trade marks: The existing economic literature.

https://www.melbourneinstitute.com/downloads/working_paper_series/wp20 $13 \mathrm{n} 25 . \mathrm{pdf}$

Greenhalgh, C., \& Rogers, M. (2007). Trade Marks and Performance in UK Firms: Evidence of Schumpeterian Competition through Innovation trieved from http://economics.ouls.ox.ac.uk/13545/1/Item.pdf

Helmers, C., \& Rogers, M. (2008). Innovation and the Survival of New Firms Across British Regions. Department of Economics Discussion Paper Series , British Regions, (416). Retrieved from http://www.economics.ox.ac.uk/Research/wp/pdf/paper416.pdf

Iversen, E. J. (2003). Norwegian small and medium-sized enterprises and the intellectual property rights system: exploration and analysis. World Intellectual Property Organization WIPO Switzerland ISBN 9280511283.

Jensen, P. H., \& Webster, E. (2006). Firm Size and the Use of Intellectual Property Rights. Economic Record, 82(256), 44-55. doi:10.1111/j.1475-4932.2006.00292.x

Krasnikov, A., Mishra, S., \& Orozco, D. (2009). Evaluating the Financial Impact of Branding Using Trademarks: A Framework and Empirical Evidence. Journal of Marketing, 73(6), 154-166. doi:10.1509/jmkg.73.6.154

Mainwaring, L., Moore, N. J., \& Murphy, P. D. (2004). Trademarks holdings of Production Firms in Britain and Ireland., 1-31.

Malmberg, C. (2005). Trademarks Statistics as Innovation Indicator? - A Micro Study (No. 17).http:/ /lup.lub.lu.se/luur/download?func $=$ downloadFile\&recordOId $=941429 \&$ fileOId $=4407$ 256

Mamede, R., \& Fernandes, T. (2011). Patterns and determinants of trademark use in Portugal.

Maskus, K. E. (2000). The economics of intellectual property rights and globalization: Dancing the dual distortion. In Intellectual Property Rights in the Global Economy (pp. 1-89). Retrieved from http://mattias.ganslandt.info/ipr/maskus_globalization.pdf

Mendonça, S., Pereira, T. S., \& Godinho, M. M. (2004). Trademarks as an indicator of innovation and industrial change. Research Policy, 33(9), 1385-1404. doi:10.1016/j.respol.2004.09.005

Millot, V. (2009). Trademarks as an Indicator of Product and Marketing Innovations. OECD Science, technology and Industry Working Papers. doi:http://dx.doi.org/10.1787/224428874418

Millot, V. (2012). Trade mark strategies and innovative activities (Doctoral dissertation, Strasbourg). 
Schwiebacher, F. (2012). How Companies Use Different Forms of IPR Protection Are Patents and $\begin{array}{llll}\text { Trademarks } \quad \text { Complements } & \text { Or } \quad \text { Substitutes? } & \text { Retrieved } & \text { from } \\ \text { http://www2.druid.dk/conferences/viewpaper.php?id=500648\&cf }=44 & & \end{array}$

WIPO. (2014). Madrid Yearly Review. Madrid Yearly Review, International Registrations of Marks. 